\title{
Knowledge Gap: Supply Chain Students and Employers
}

\author{
Kathryn Bules, Sime Curkovic, Paula Eckert, Christina Stamper \\ Department of Management, Western Michigan University, Haworth College of Business, Kalamazoo, MI, USA \\ Email: sime.curkovic@wmich.edu
}

How to cite this paper: Bules, K., Curkovic, S., Eckert, P., \& Stamper, C. (2019). Knowledge Gap: Supply Chain Students and Employers. Creative Education, 10, 814-830.

https://doi.org/10.4236/ce.2019.104060

Received: March 29, 2019

Accepted: April 26, 2019

Published: April 29, 2019

Copyright () 2019 by author(s) and Scientific Research Publishing Inc. This work is licensed under the Creative Commons Attribution International License (CC BY 4.0).

http://creativecommons.org/licenses/by/4.0/

\begin{abstract}
This research aims to identify the gaps between supply chain students and employers for both the preparedness and relative importance of the critical job skills employers seek in graduating students. This research is relevant because students view college as an investment that will pay off through better job placement and higher pay upon graduation. The problem is that some employers feel students do not have the skills necessary to be successful on the job. While there has been extensive research regarding a skills gap in graduating students and common criteria employers use to rank these students, there is minimal research analyzing the gap specifically within supply chain management (SCM). The methodology of this study includes the analysis of existing research and original data collected from a sample of employers and students. The first step involved leveraging existing research to determine the top ten skills employers seek in recent SCM graduates. Next, an electronic survey was created that sought to identify both the feeling of preparedness and relative importance of the predetermined skills. This survey was then sent to a sample of juniors and seniors majoring in SCM and employers that hire students to fill supply chain-related roles. The results of the survey were analyzed to establish if there is a significant difference in responses between students and employers. Finally, recommendations will be given that aim to bridge the gaps. The overall goal of this research is to help students understand expectations of employers and how students can capitalize on their time in college to meet those expectations.
\end{abstract}

\section{Keywords}

Supply Chain Management, Experiential Learning, Problem-Solving, Employer, Students

\section{Introduction}

APICS (The Association for Operations Management) is the premier member- 
ship organization providing education, certification, and career development opportunities to supply chain professionals worldwide. The APICS Certified Supply Chain Professional (CSCP) Learning System and corresponding certification give professionals the knowledge and skills they need to be successful. In recognition of this, APICS developed the Supply Chain Manager Competency Survey and Model to guide individuals considering careers in supply chain management, supply chain professionals seeking to advance their positions, and human resource managers who are hiring in this fast-growing field. In their survey, college freshmen were asked why they chose to attend college, and $86.1 \%$ of respondents said a very important reason was "to get a better job." $72.8 \%$ of respondents also shared they pursued college because they wanted to make more money. This number had increased by 28.3\% from 1971 to 2014 (Rampell, 2018). These findings by the Higher Education Research Institute at U.C.L.A. demonstrate that young Americans are pursuing higher education with the goal of attaining a better job with higher pay. Unfortunately, achieving this goal has become an increasingly larger investment for students as the cost of tuition continues to rise. The National Center for Education Statistics found that the average yearly cost of tuition at a public, 4-year institution has increased from $\$ 8238$ in 1984 to $\$ 18,632$ in 2015 (U.S. Department of Education, 2015). With over a $\$ 10,000$ increase in tuition costs during the past thirty years, it is vital that students are being properly prepared for a post-graduation career that will provide a return on their investment. However, some employers feel students are underperforming in key areas they seek in job candidates. Employer research conducted by Maguire Associates Inc. found that recent graduates lacked skills such as effective communication, decision making, and analytical capabilities (Fischer, 2013). This indicates students are either not receiving coursework that enhances these skills through their college education, or students could be unaware they are not as proficient as employers expect in these areas. The student-employer disconnect is the primary reason for this exploratory study.

\section{Data Collection Method}

All data was collected through an anonymous online survey created by the authors using Qualtrics survey software. The survey consisted of several non-identifying demographic questions and two sections where participants were asked to rank a series of variables. Both employers and students were recruited for this survey through email. The student email list was obtained from the Integrated Supply Management (ISM) academic advisor and consisted of all juniors and seniors majoring in ISM/SCM during Fall 2018 at Western Michigan University (WMU). Employer contact information was obtained through a professional advisory council that advises the ISM program on curriculum development. All survey participation was completely voluntary.

\section{Survey Content}

This survey was constructed to collect data around common attributes employ- 
ers use to rank recent graduates who apply to supply-chain related roles. These attributes were determined using data collected by the National Association of Colleges and Employers (Gray \& Koncz, 2017) and The American Production and Inventory Control Society (Supply Chain Manager Competency Model, 2014). Combining information presented by both of these sources, the following attributes were included in the survey:

1) College Major

2) College GPA

3) Study Abroad Experience

4) Internship Experience

5) Involved in Extracurricular Activities

6) Technical Skills

7) Written Communication Skills

8) Verbal Communication Skills

9) Ability to Work in a Team

10) Problem Solving

To remove bias from the participant's individual interpretation of attributes, definitions were listed for the following attributes: Technical Skills, Communication Skills, Ability to Work in a Team, and Problem Solving. Employers and students were asked to rank the attributes listed above based on the following statements:

\subsection{Student Survey}

1) "Please rank the following based on how important you believe each attribute is to employers when hiring supply chain management college graduates."

2) "Please rank the following based on how competent/prepared you feel you are in each of the categories."

\subsection{Employer Survey}

1) "Please rank the following based on how important you believe each attribute is when hiring supply chain management college graduates."

2) "Please rank the following based on how competent/prepared you feel students are in each of the categories."

Please refer to Appendix A (Student Survey) and Appendix B (Employer Survey) to view the full survey.

\section{Population Description}

\subsection{Student Population}

This study was designed to be strictly exploratory in nature, and there was no hypothesis it was trying to prove or disprove. Instead, this study aimed to capture student and employer opinions regarding popular attributes used to rank recent graduates in hiring decisions for SCM roles. There are certain limitations 
that may have impacted results of this study. The student study sample does not reflect the true population of all SCM majors at WMU or other schools. The sample of students that participated in this study is derived from the entire population of juniors and seniors majoring in ISM/SCM at WMU. Table 1 provides basic demographic information for both the population and the study sample.

As seen in Table 1, there is a slightly higher proportion of seniors represented in the study sample than there is in the true population. Additionally, the proportion of females represented in the study sample is also greater than that of the true proportion.

Figure 1 and Figure 2 indicate the proportion of students in the study sample with study abroad experience and/or with internship experience.

Table 1. Demographic information for population and study sample of ISM/SCM majors at WMU.

\begin{tabular}{ccc}
\hline Demographic Category & Population & Study Sample \\
\hline Size & $\mathrm{n}=226$ & $\mathrm{n}=31$ \\
\% of Juniors & $34.5 \%$ & $25.8 \%$ \\
\% of Seniors & $65.5 \%$ & $74.2 \%$ \\
\% of Females & $23.5 \%$ & $45.2 \%$ \\
\% of Males & $76.5 \%$ & $54.8 \%$ \\
\hline
\end{tabular}

*Population data based on fall 2018 supply chain majors at Western Michigan University.

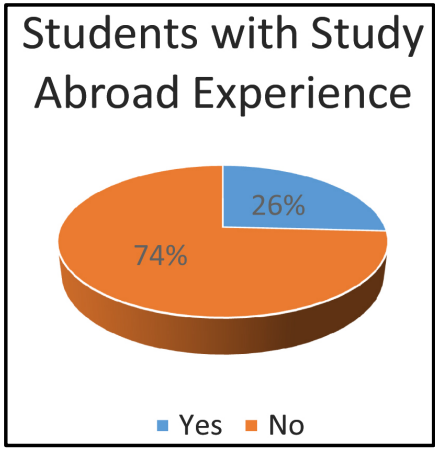

Figure 1. Proportion of students with study abroad experience.

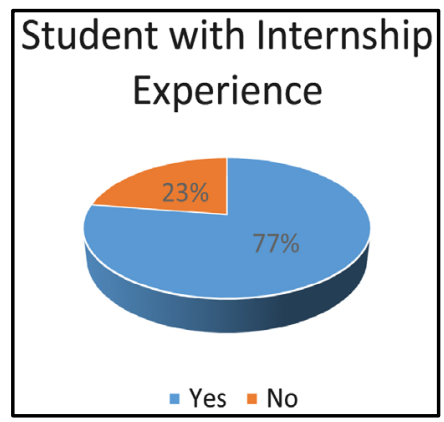

Figure 2. Proportion of students with internship experience. 


\subsection{Employer Population}

The sample of employers that participated in this study is derived from all employers that commonly recruit students majoring in ISM at WMU. The exact number of employers in the true population is unknown. However, basic demographic information for the study sample consisting of 25 employers is outlined in Table 2.

The largest number of employers that participated in this study are in the manufacturing industry (6) followed by the consumer product industry (4) and the food/beverage industry (3). The high number of companies involved in the manufacturing industry is representative of the large number of manufacturing companies located in the Midwest that recruit from WMU. As can be seen in Figure 3, 72\% of participating employers categorize themselves as a large company, meaning they employ over 1000 people.

Table 2. Company industries represented in the study sample.

\begin{tabular}{|c|c|}
\hline Company Industry & Number of Companies \\
\hline Aerospace & 1 \\
\hline Banking and Technology & 1 \\
\hline Chemical & 1 \\
\hline Consumer Products & 4 \\
\hline Food/Beverage Industry & 3 \\
\hline Home Appliance & 1 \\
\hline Horticulture & 1 \\
\hline Industrial & 1 \\
\hline Industrial Fluid Power & 1 \\
\hline Manufacturing & 6 \\
\hline Marine & 1 \\
\hline Medical Device & 1 \\
\hline Numeric Valves & 1 \\
\hline Regional Corporate Center & 1 \\
\hline Transportation & 1 \\
\hline
\end{tabular}

\section{Company Size}

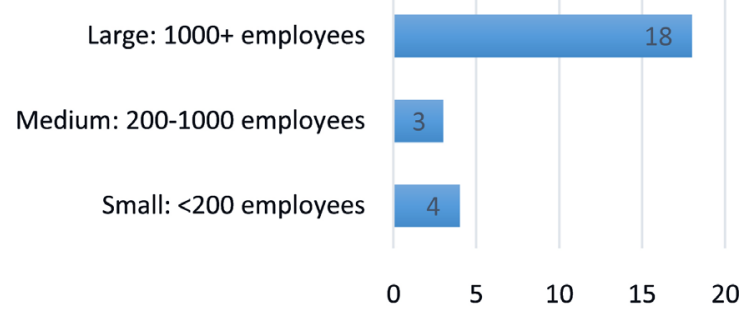

Figure 3. Size of companies that participated in the study. 


\section{Data}

\subsection{Summary Statistics-Importance of Attributes}

Table 3 summarizes the response data for both employers and students when asked to rank the importance of the listed attributes in hiring decisions for SCM roles. Results are based on the following scale:

$$
\begin{aligned}
& 1=\text { Not at all Important } \\
& 2=\text { Slightly Important } \\
& 3=\text { Moderately Important } \\
& 4=\text { Very Important } \\
& 5=\text { Extremely Important }
\end{aligned}
$$

As seen in Table 3, student mean rankings for school-related attributes such as college major, college GPA, study abroad experience, and extracurricular involvement are greater than employer mean rankings of the same attributes. This suggests students place higher importance on school-related activities than employers when applying to full time jobs. On the other hand, employer top four mean rankings are focused on personality-based traits: written communication skills, verbal communication skills, ability to work in a team, and problem solving. This indicates employers place less emphasis on school-related activities and care more about a student's soft skills. Both students and employers have the highest mean ranking for "problem solving" and the lowest mean ranking for

\begin{tabular}{|c|c|c|c|c|c|c|}
\hline \multirow{2}{*}{$\begin{array}{c}\text { Importance of Attributes } \\
\text { Attribute }\end{array}$} & \multicolumn{3}{|c|}{ Employer $n=25$} & \multicolumn{3}{|c|}{ Student $\mathrm{n}=31$} \\
\hline & Mean & Median & $\begin{array}{l}\text { Standard } \\
\text { Deviation }\end{array}$ & Mean & Median & $\begin{array}{l}\text { Standard } \\
\text { Deviation }\end{array}$ \\
\hline College Major & 3.62 & 4 & 0.79 & 4.16 & 4 & 0.92 \\
\hline College GPA & 3.38 & 3 & 0.79 & 3.77 & 4 & 0.91 \\
\hline Study Abroad Experience & 1.85 & 2 & 0.82 & 2.55 & 3 & 0.94 \\
\hline Internship Experience & 4.31 & 4 & 0.67 & 4.55 & 5 & 0.61 \\
\hline $\begin{array}{c}\text { Involved in Extracurricular } \\
\text { Activities }\end{array}$ & 3.08 & 3 & 0.96 & 3.74 & 4 & 0.76 \\
\hline Technical Skills & 3.96 & 4 & 0.9 & 4.06 & 4 & 0.8 \\
\hline $\begin{array}{c}\text { Written Communication } \\
\text { Skills }\end{array}$ & 4.42 & 4 & 0.57 & 4.1 & 4 & 0.86 \\
\hline $\begin{array}{c}\text { Verbal Communication } \\
\text { Skills }\end{array}$ & 4.46 & 4 & 0.57 & 4.52 & 5 & 0.67 \\
\hline Ability to Work in a Team & 4.54 & 5 & 0.57 & 4.77 & 5 & 0.42 \\
\hline Problem Solving & 4.58 & 5 & 0.57 & 4.84 & 5 & 0.37 \\
\hline
\end{tabular}
"study abroad experience." However, student mean rankings for study abroad experience was 2.55 , while employer mean ranking was only 1.85 .

Table 3. Student and employer response data regarding the importance of listed attributes in hiring decisions. 


\subsection{Summary Statistics-Student Competency of Attributes}

Table 4 summarizes the response data for both employers and students when asked to rank the importance of the listed attributes in hiring decisions for SCM roles. Results are based on the following scale:

$$
\begin{aligned}
& 1=\text { Very Poor } \\
& 2=\text { Poor } \\
& 3=\text { Fair } \\
& 4=\text { Good } \\
& 5=\text { Excellent }
\end{aligned}
$$

Based on the mean rankings in Table 4, students feel they are most competent in their teamwork abilities, while employers viewed their highest competency as internship experience. With the exception of study abroad experience, the student mean ranking for each attribute is higher than the employer mean ranking. This indicates students view themselves as more competent job candidates than the employers do. Additionally, 3 out of the top 4 employer mean rankings of student competency were for school-related attributes (i.e., internship experience, ability to work in a team, and college GPA). This could be attributed to students' high perceived importance of these attributes reflected in the previous table. Students focus their efforts on improving themselves in these areas because they believe these attributes are highly influential in their chances of being hired into a full-time role upon graduation.

\subsection{Analysis}

Figure 4 displays the difference between student mean rankings and employer

\begin{tabular}{|c|c|c|c|c|c|c|}
\hline \multirow{2}{*}{$\begin{array}{c}\text { Student Competency of } \\
\text { Attributes } \\
\text { Attribute }\end{array}$} & \multicolumn{3}{|c|}{ Employer $n=25$} & \multicolumn{3}{|c|}{ Student $\mathrm{n}=31$} \\
\hline & Mean & Median & $\begin{array}{l}\text { Standard } \\
\text { Deviation }\end{array}$ & Mean & Median & $\begin{array}{l}\text { Standard } \\
\text { Deviation }\end{array}$ \\
\hline College GPA & 3.88 & 4 & 0.59 & 4.35 & 4 & 0.65 \\
\hline Study Abroad Experience & 2.96 & 3 & 0.87 & 2.32 & 3 & 1.63 \\
\hline Internship Experience & 4.04 & 4 & 0.72 & 4.23 & 5 & 1.07 \\
\hline $\begin{array}{c}\text { Involved in Extracurricular } \\
\text { Activities }\end{array}$ & 3.64 & 4 & 0.69 & 3.97 & 4 & 1.09 \\
\hline Technical Skills & 3.4 & 3 & 0.63 & 4.19 & 4 & 0.64 \\
\hline Written Communication Skills & 3.64 & 4 & 0.74 & 4.29 & 4 & 0.58 \\
\hline Verbal Communication Skills & 3.6 & 4 & 0.63 & 4.26 & 4 & 0.57 \\
\hline Ability to Work in a Team & 3.92 & 4 & 0.48 & 4.74 & 5 & 0.44 \\
\hline Problem Solving & 3.4 & 3 & 0.69 & 4.52 & 5 & 0.56 \\
\hline
\end{tabular}
mean rankings of a student's competencies in problem solving, ability to work in a team, and verbal communication skills. These three attributes represent the

Table 4. Student and employer response data regarding students' competency of the listed attributes. 


\section{Student Competency: Employer vs Student}

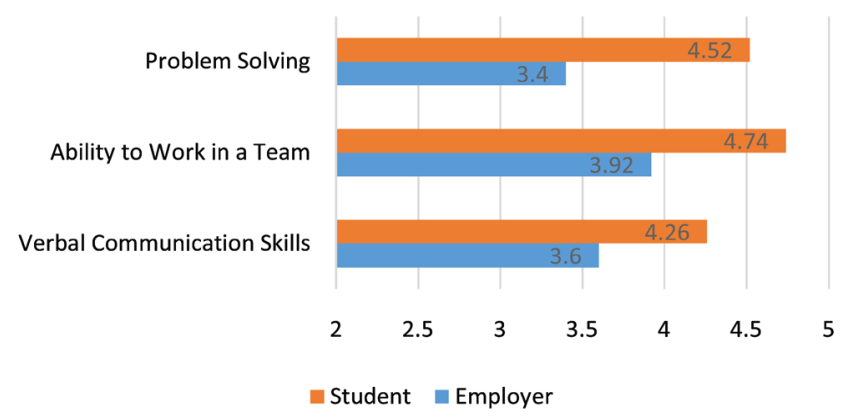

Figure 4. Difference between student mean rankings and employer mean rankings of student's competencies.

employer top-ranked attributes in hiring decisions for SCM roles.

Based on two sample t-tests with an alpha level of 0.05 , the difference in the mean ranking between students and employers for each attribute is statistically significant (Appendix C). This data suggests students are not as prepared as they think they are in employer top-ranked attributes for selecting job candidates.

Figure 5 compares student mean rankings and employer mean rankings of the importance of study abroad experience in employer hiring decisions.

Although both student and employer lowest-ranking attribute is study abroad experience, there is still a noticeable difference in their mean scores. The data indicates students feel study abroad experience is more important in their overall chances of obtaining employment than employers do. This suggests study abroad experience is not vital for recent graduates to obtain employment in a SCM-related role.

Another notable difference between student and employer views on the importance of attributes can be seen in Figure 6.

Student mean rankings for the importance of school-related attributes is consistently greater than employer mean rankings of the same attributes. Based on an alpha level of 0.05, a two-sample t-Test reveals all of these differences are statistically significant with the exception of internship experience (Appendix D). This indicates students are placing a greater importance on extracurricular involvement, GPA, and major than they need to. The data in this study shows employers actually value communication skills, teamwork abilities, and problem solving skills over these school-related attributes.

Figure 7 compares student mean ranking and employer mean rankings of student competency in the listed attributes. Figure 7 shows students feel they are more competent/prepared in areas such as problem solving, technical skills, and teamwork skills than employers believe they are.

\section{Implications}

This study was designed to be exploratory in nature, and there was no hypothesis it was trying to prove or disprove. Instead, this study aimed to capture student 


\section{Importance of Study \\ Abroad Experience}

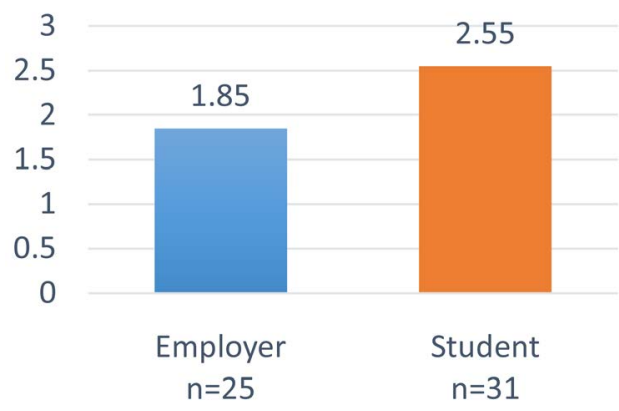

Figure 5. Comparison of student and employer mean rankings of the importance of study abroad experience in employer hiring decisions.

\section{School-Related Attribute Importance}

Involved in Extracurricular Activities

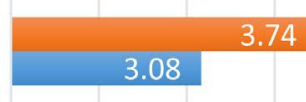

Internship Experience

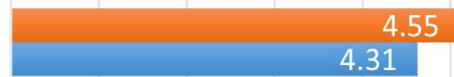

College GPA

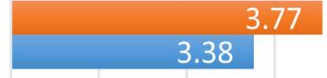

College Majo

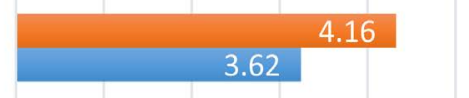

$\begin{array}{lllllll}2 & 2.5 & 3 & 3.5 & 4 & 4.5 & 5\end{array}$

- Student Employer

Figure 6. Comparison of student mean rankings and employer mean rankings for the importance of school-related attributes.

\section{Competency Ratings}

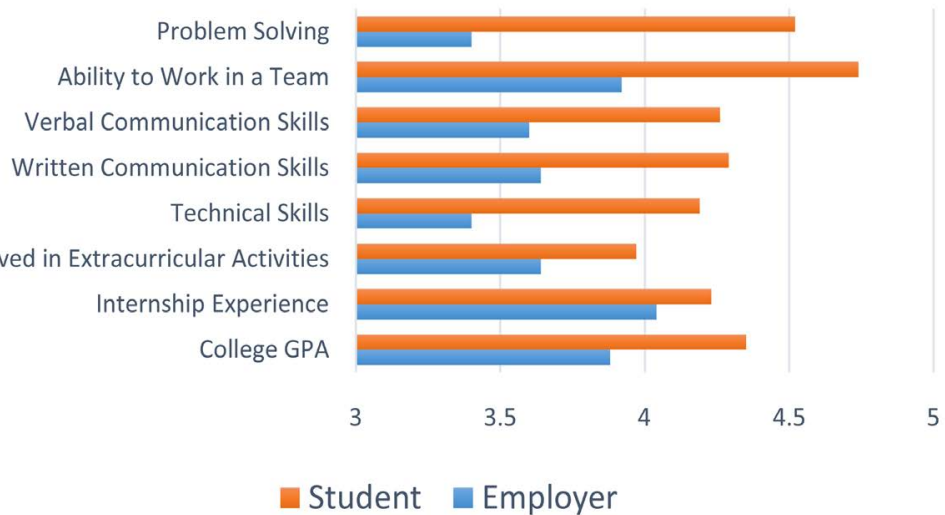

Figure 7. Student mean ranking and employer mean rankings of student competency in the listed attributes. 
and employer opinions regarding popular attributes used to rank recent graduates in hiring decisions for SCM roles. Analysis of the data aides in identifying any gaps in these opinions. Understanding where the gap lies is the first step to addressing the disconnect between students and employers in hiring criteria expectations. Based on the analysis, students tend put more importance on school-related attributes than employers do. These attributes include college major, college GPA, study abroad experience, and extracurricular involvement. A possible reason students think this way can be attributed to the atmosphere upheld around a college campus. There is pressure to maintain high grades and display an above-average GPA at the top of one's resume. Additionally, posters, emails, and in-class presentations encourage students to join a multitude of organizations during their college career. However, the employer data suggests employers view skills such as verbal/written communication skills, problem solving, and ability to work in a team as the most important attributes for job candidates. Students may want to focus on developing these skills and conveying them to recruiters through their resume and interviews. Listed below are possible ways in which students can develop these skills:

- Sign up for practice interviews to develop interviewing skills. This will both improve the student's ability to verbally communicate during the interview, and it can help them understand what skills they should try to convey to a potential employer.

- Apply for a case competition. Case competitions focus on solving a real-world business problem by collaborating with a team and presenting the results to a panel of judges. This experience requires a student to use all of the skills mentioned above and will help that student enhance those skills.

- Showcase examples of these skills to employers through work experiences or extracurricular involvements. Although internship experience and extracurricular activities are not at the top of employer attribute rankings, they can be a good way to provide examples of how a student uses the soft skills employers seek to carry out their duties in that role.

Another implication of these results is that study abroad experience is not very important to employers in comparison to the other attributes included in this study. Studying abroad is heavily promoted to students in college, but can be costly for students and difficult to fit in their busy schedules. If a student is unable to go abroad when earning their degree, this data suggests employers will not take that into heavy consideration during their hiring decisions. For nearly every attribute, students ranked themselves as more competent than employers felt they actually were for that attribute. This implies students feel they are more qualified for certain positions than employers view them as. As a result, some students may not be actively trying to improve certain skills that could better their chances of obtaining employment upon graduation. A possible remedy to this problem is increased transparency between employers and students. Employers could be asked to complete an anonymous survey after on campus events such as career fairs regarding where students exceeded their expectations, 
and what traits they believe students should develop. Sharing a summary of the results with students and faculty would allow for valuable insights on how students can make themselves a better candidate for potential employers.

\section{Limitations}

There are certain limitations that may have impacted results of this study. The student study sample does not reflect the true population of all SCM majors at WMU or other schools. The proportion of female participants (45.2\%) is much higher than the true proportion of females in the program (23.5\%). Additionally, the true population of all employers that recruit from the program is unknown, so the study sample may not reflect the views of the entire employer population. Also, participants may have interpreted the attributes in different ways. As a result, their ranking could have been influenced differently than another participant's ranking who held a different view on the attribute.

The analysis portion of this study compares employer results to student results for student competency of hiring attributes. However, the employers may have never interviewed the individual students that participated in the survey. Therefore, their "student competency" ranking may not directly reflect the competency of the students who took the survey. Finally, this survey was voluntary for all participants. The type of person that is willing to complete the survey may differ from those that do not take the time to complete a student survey. Therefore, the beliefs of non-responders may not be captured in the survey results.

\section{Conclusion}

Overall, this study shows some gaps exist between employer and student opinions around attributes used to rank candidates in hiring decisions. Students place greater importance on school-related attributes, while employers favor soft skills such as teamwork abilities and verbal/written communication skills. Additionally, students ranked themselves as more competent in each of the categories than employer ranking of students. This research aimed to increase transparency and demonstrated where the gaps exist between students and employers. When these gaps are minimized, students will better understand the expectations of their future employers and can choose to focus their limited resources on improving the attributes employers view as the most important in their hiring decisions.

\section{Conflicts of Interest}

The authors declare no conflicts of interest regarding the publication of this paper.

\section{References}

Fischer, K. (2013). The Employment Mismatch. The Chronicle of Higher Education. 
https://www.chronicle.com/article/The-Employment-Mismatch/137625

Gray, K., \& Koncz, A. (2017). The Key Attributes Employers Seek on Students' Resumes (Publication). National Association of Colleges and Employers Website.

http://www.naceweb.org/about-us/press/2017/the-key-attributes-employers-seek-on-st udents-resumes/

Supply Chain Manager Competency Model (2014).

http://www.apics.org/docs/default-source/careers-competency-models/supply-chain-m anager-competency-model.pdf

Rampell, C. (2018). Why Do Americans Go to College? First and Foremost, They Want Better Jobs. Washington Post.

https://www.washingtonpost.com/news/rampage/wp/2015/02/17/why-do-americans-g o-to-college-first-and-foremost-they-want-better-jobs/?utm_term=.a3968faf3261

U.S. Department of Education, National Center for Education Statistics (2016). Digest of Education Statistics, 2015 (NCES 2016-014).

http://nces.ed.gov/programs/digest/d15/tables/dt15_330.10.asp 


\section{Appendix A-Student Survey}

Please use the following definitions for reference as you complete the survey.

- Technical Skills-include, but are not limited to: Excel, SAP, statistical analysis tools, Access.

- Communication Skills- "Express information to individuals or groups considering the audience and the nature of the information (e.g., technical or controversial); speak clearly and confidently; organize information in a logical manner; receive, attend to, interpret, understand, and respond to verbal messages and other cues; pick out important information in verbal messages; persuasively present thoughts and ideas."

- Ability to Work in a Team- "Demonstrate a commitment to the mission and motivation to combine the team's energy and expertise to achieve a common objective."

- Problem Solving- "Demonstrate ability to map processes of possible consequences of decisions, to work out the importance of individual factors, and to choose the best course of action; Develop the capacity to think in a careful and discerning way, to solve problems, to analyze data, and to recall and apply information."

${ }^{\star}$ Definitions from APICS: Supply Chain Manager Competency Model.

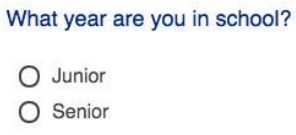

Please rank the following based on how important you believe each attribute is to employers when hiring supply chain management college graduates.

\begin{tabular}{|c|c|c|c|c|c|}
\hline & $\begin{array}{l}\text { Not at all } \\
\text { important }\end{array}$ & $\begin{array}{l}\text { Slightly } \\
\text { important }\end{array}$ & $\begin{array}{c}\text { Moderately } \\
\text { important }\end{array}$ & $\begin{array}{l}\text { Very } \\
\text { important }\end{array}$ & $\begin{array}{l}\text { Extremely } \\
\text { important }\end{array}$ \\
\hline College Major & $\mathrm{O}$ & $\mathrm{O}$ & O & O & O \\
\hline College GPA & $\mathrm{O}$ & $\mathrm{O}$ & $\mathrm{O}$ & $\mathrm{O}$ & O \\
\hline $\begin{array}{l}\text { Study Abroad } \\
\text { Experience }\end{array}$ & $\mathrm{O}$ & $\mathrm{O}$ & O & $\mathrm{O}$ & O \\
\hline Internship Experience & $\mathrm{O}$ & $\mathrm{O}$ & O & $\mathrm{O}$ & $\mathrm{O}$ \\
\hline $\begin{array}{l}\text { Involved in } \\
\text { Extracurricular } \\
\text { Activities }\end{array}$ & $\mathrm{O}$ & $\mathrm{O}$ & O & $\mathrm{O}$ & $\mathrm{O}$ \\
\hline Technical Skills & $\mathrm{O}$ & $\mathrm{O}$ & O & O & O \\
\hline $\begin{array}{l}\text { WrittenCommunication } \\
\text { Skills }\end{array}$ & $\mathrm{O}$ & $\mathrm{O}$ & $\mathrm{O}$ & $\mathrm{O}$ & O \\
\hline $\begin{array}{l}\text { Verbal Communication } \\
\text { Skills }\end{array}$ & $\mathrm{O}$ & $\mathrm{O}$ & O & $\mathrm{O}$ & $\mathrm{O}$ \\
\hline $\begin{array}{l}\text { Ability to Work in a } \\
\text { Team }\end{array}$ & $\mathrm{O}$ & $\mathrm{O}$ & O & $\mathrm{O}$ & O \\
\hline Problem Solving & O & O & 0 & O & O \\
\hline
\end{tabular}


Please rank the following based on how competent/prepared you feel you are in each of the categories.

\begin{tabular}{|c|c|c|c|c|c|}
\hline & Very Poor & Poor & Fair & Good & Excellent \\
\hline GPA & O & 0 & 0 & O & 0 \\
\hline $\begin{array}{l}\text { Study Abroad } \\
\text { Experience }\end{array}$ & $\mathrm{O}$ & $\mathrm{O}$ & $\mathrm{O}$ & $\mathrm{O}$ & $\mathrm{O}$ \\
\hline Internship Experience & $\mathrm{O}$ & 0 & $\mathrm{O}$ & O & 0 \\
\hline $\begin{array}{l}\text { Involved in } \\
\text { Extracurricular } \\
\text { Activities }\end{array}$ & O & 0 & 0 & O & O \\
\hline Technical Skills & $\mathrm{O}$ & 0 & 0 & 0 & $\mathrm{O}$ \\
\hline $\begin{array}{l}\text { Written } \\
\text { Communication Skills }\end{array}$ & $\mathrm{O}$ & $\mathrm{O}$ & 0 & 0 & 0 \\
\hline $\begin{array}{l}\text { Verbal Communication } \\
\text { Skills }\end{array}$ & $\mathrm{O}$ & 0 & $\mathrm{O}$ & O & O \\
\hline $\begin{array}{l}\text { Ability to Work in a } \\
\text { Team }\end{array}$ & O & $\mathrm{O}$ & $\mathrm{O}$ & O & O \\
\hline Problem Solving & $\mathrm{O}$ & 0 & 0 & 0 & 0 \\
\hline
\end{tabular}

\section{Appendix B-Employer Survey}

Please use the following definitions for reference as you complete the survey.

- Technical Skills-include, but are not limited to: Excel, SAP, statistical analysis tools, Access

- Communication Skills-"Express information to individuals or groups considering the audience and the nature of the information (e.g., technical or controversial); speak clearly and confidently; organize information in a logical manner; receive, attend to, interpret, understand, and respond to verbal messages and other cues; pick out important information in verbal messages; persuasively present thoughts and ideas."

- Ability to Work in a Team-"Demonstrate a commitment to the mission and motivation to combine the team's energy and expertise to achieve a common objective."

- Problem Solving_-"Demonstrate ability to map processes of possible consequences of decisions, to work out the importance of individual factors, and to choose the best course of action; Develop the capacity to think in a careful and discerning way, to solve problems, to analyze data, and to recall and apply information."

*Definitions from APICS: Supply Chain Manager Competency Model

What is the size of your company?

Small: $<200$ emoloyees

Medium: 200-1000 employees

Large: $1000+$ employees

Please specify which industry your company is in 
Please rank the following based on how important you believe each attribute is when hiring supply chain management college graduates.

\begin{tabular}{|c|c|c|c|c|c|}
\hline & $\begin{array}{l}\text { Not at all } \\
\text { Important }\end{array}$ & $\begin{array}{l}\text { Slightly } \\
\text { important }\end{array}$ & $\begin{array}{l}\text { Moderately } \\
\text { important }\end{array}$ & $\begin{array}{c}\text { Very } \\
\text { important }\end{array}$ & $\begin{array}{l}\text { Extremely } \\
\text { important }\end{array}$ \\
\hline College Major & $\mathrm{O}$ & O & 0 & 0 & 0 \\
\hline College GPA & $\mathrm{O}$ & $\mathrm{O}$ & O & 0 & $\mathrm{O}$ \\
\hline $\begin{array}{l}\text { Study Abroad } \\
\text { Experience }\end{array}$ & $\mathrm{O}$ & $\mathrm{O}$ & O & $\mathrm{O}$ & $\mathrm{O}$ \\
\hline Internship Experience & $\mathrm{O}$ & $\mathrm{O}$ & $\mathrm{O}$ & $\mathrm{O}$ & $\mathrm{O}$ \\
\hline $\begin{array}{l}\text { Involved in } \\
\text { Extracurricular } \\
\text { Activities }\end{array}$ & $\mathrm{O}$ & $\mathrm{O}$ & O & $\mathrm{O}$ & 0 \\
\hline Technical Skills & $\mathrm{O}$ & $\mathrm{O}$ & $\mathrm{O}$ & 0 & $\mathrm{O}$ \\
\hline $\begin{array}{l}\text { Written } \\
\text { Communication Skills }\end{array}$ & $\mathrm{O}$ & $\mathrm{O}$ & $\mathrm{O}$ & $\mathrm{O}$ & O \\
\hline $\begin{array}{l}\text { Verbal Communication } \\
\text { Skills }\end{array}$ & $\mathrm{O}$ & $\mathrm{O}$ & $\mathrm{O}$ & 0 & $\mathrm{O}$ \\
\hline $\begin{array}{l}\text { Ability to Work in a } \\
\text { Team }\end{array}$ & $\mathrm{O}$ & $\mathrm{O}$ & O & O & $\mathrm{O}$ \\
\hline Problem Solving & $\mathrm{O}$ & 0 & 0 & 0 & 0 \\
\hline
\end{tabular}

Please rank the following based on how competent/prepared you feel students are in each of the categories.

$\begin{array}{lccccc} & \text { Very Poor } & \text { Poor } & \text { Fair } & \text { Good } & \text { Excellent } \\ \text { College GPA } & 0 & 0 & 0 & 0 & 0 \\ \begin{array}{l}\text { Study Abroad } \\ \text { Experience }\end{array} & 0 & 0 & 0 & 0 & 0 \\ \begin{array}{l}\text { Internship Experience } \\ \begin{array}{l}\text { Involved in } \\ \text { Extracurricular }\end{array}\end{array} & 0 & 0 & 0 & 0 & 0 \\ \begin{array}{l}\text { Activities } \\ \text { Technical Skills }\end{array} & 0 & 0 & 0 & 0 & 0 \\ \begin{array}{l}\text { Written } \\ \text { Communication Skills }\end{array} & 0 & 0 & 0 & 0 & 0 \\ \begin{array}{l}\text { Verbal Communication } \\ \text { Skills }\end{array} & 0 & 0 & 0 & 0 & 0 \\ \begin{array}{l}\text { Ability to Work in a } \\ \text { Team }\end{array} & 0 & 0 & 0 & 0 & 0 \\ \begin{array}{l}\text { Problem Solving } \\ \text { ( }\end{array} & 0 & 0 & 0 & 0 & 0\end{array}$

\section{Appendix C-Two Sample T-Tests: Student Competency}

1) Attribute: Verbal Communication Skills-Student Competency

Variable $1=$ Employer Ranking

Variable 2 = Student Ranking

Ho: $\bar{x}_{1}=\bar{x}_{2}$

Ha: $\bar{x}_{1} \neq \bar{x}_{2}$

\begin{tabular}{|c|c|c|}
\hline \multicolumn{3}{|c|}{$\begin{array}{l}\text { t-Test: Two-Sample Assuming Unequal Variances } \\
\text { Attribute: Verbal Communication Skills }\end{array}$} \\
\hline & Variable 1 & Variable 2 \\
\hline Mean & 3.6 & 4.258064516 \\
\hline Variance & 0.416666667 & 0.331182796 \\
\hline Observations & 25 & 31 \\
\hline Hypothesized Mean Difference & 0 & \\
\hline df & 49 & \\
\hline t Stat & 3.979146657 & \\
\hline $\mathrm{P}(\mathrm{T}<=\mathrm{t})$ one-tail & 0.000114051 & \\
\hline t Critical one-tail & 1.676550893 & \\
\hline $\mathrm{P}(\mathrm{T}<=\mathrm{t})$ two-tail & 0.000228101 & \\
\hline t Critical two-tail & 2.009575237 & \\
\hline
\end{tabular}


2) Attribute: Ability to Work in a Team-Student Competency

Variable 1 = Employer Ranking

Variable 2 = Student Ranking

Ho: $\bar{x}_{1}=\bar{x}_{2}$

Ha: $\bar{x}_{1} \neq \bar{x}_{2}$

\begin{tabular}{|c|c|c|}
\hline \multicolumn{3}{|c|}{$\begin{array}{l}\text { t-Test: Two-Sample Assuming Unequal Variances } \\
\text { Attribute: Teamwork }\end{array}$} \\
\hline & Variable 1 & Variable 2 \\
\hline Mean & 3.92 & 4.741935484 \\
\hline Variance & 0.243333333 & 0.197849462 \\
\hline Observations & 25 & 31 \\
\hline Hypothesized Mean Difference & 0 & \\
\hline df & 49 & \\
\hline t Stat & 6.474628278 & \\
\hline$P(T<=t)$ one-tail & $2.16176 \mathrm{E}-08$ & \\
\hline t Critical one-tail & 1.676550893 & \\
\hline$P(T<=t)$ two-tail & $4.32352 \mathrm{E}-08$ & \\
\hline t Critical two-tail & 2.009575237 & \\
\hline
\end{tabular}

3) Attribute: Problem Solving-Student Competency

Variable 1 = Employer Ranking

Variable 2 = Student Ranking

Ho: $\bar{x}_{1}=\bar{x}_{2}$

Ha: $\bar{x}_{1} \neq \bar{x}_{2}$

\begin{tabular}{|c|c|c|}
\hline \multicolumn{3}{|c|}{$\begin{array}{l}\text { t-Test: Two-Sample Assuming Unequal Variances } \\
\text { Attribute: Problem Solving }\end{array}$} \\
\hline & Variable 1 & Variable 2 \\
\hline Mean & 3.4 & 4.516129032 \\
\hline Variance & 0.5 & 0.324731183 \\
\hline Observations & 25 & 31 \\
\hline Hypothesized Mean Difference & 0 & \\
\hline$d f$ & 46 & \\
\hline t Stat & 6.393536174 & \\
\hline $\mathrm{P}(\mathrm{T}<=\mathrm{t})$ one-tail & $3.71365 \mathrm{E}-08$ & \\
\hline t Critical one-tail & 1.678660414 & \\
\hline$P(T<=t)$ two-tail & $7.42731 \mathrm{E}-08$ & \\
\hline t Critical two-tail & 2.012895599 & \\
\hline
\end{tabular}

\section{Appendix D-Two Sample T-Tests: Attribute Importance}

1) Attribute: College Major-Importance

Variable $1=$ Employer Ranking

Variable 2 = Student Ranking

Ho: $\bar{x}_{1}=\bar{x}_{2}$

Ha: $\bar{x}_{1} \neq \bar{x} 2$

\begin{tabular}{|ccc|}
\hline \multicolumn{3}{|l|}{ t-Test: Two-Sample Assuming Unequal Variances } \\
Attribute: College Major & & \\
\hline & Variable 1 & Variable 2 \\
\hline Mean & 3.56 & 4.129032258 \\
Variance & 0.59 & 0.849462366 \\
Observations & 25 & 31 \\
Hypothesized Mean & & \\
Difference & 0 & \\
df & 54 & \\
t Stat & 2.519667494 & \\
$\mathrm{P}(\mathrm{T}<=\mathrm{t})$ one-tail & 0.007368637 & \\
t Critical one-tail & 1.673564906 & \\
$\mathrm{P}(\mathrm{T}<=\mathrm{t})$ two-tail & 0.014737274 & \\
$\mathrm{t}$ Critical two-tail & 2.004879288 & \\
\end{tabular}


2) Attribute: College GPA-Importance

\begin{tabular}{|c|c|c|}
\hline \multicolumn{3}{|c|}{$\begin{array}{l}\text { Ho: } \bar{x}_{1}=\bar{x}_{2} \\
\text { Ha: } \bar{x}_{1} \neq \bar{x}_{2}\end{array}$} \\
\hline \multicolumn{3}{|c|}{$\begin{array}{l}\text { t-Test: Two-Sample Assuming Unequal Variances } \\
\text { Attribute: College GPA }\end{array}$} \\
\hline & Variable 1 & Variable 2 \\
\hline Mean & 3.32 & 3.774193548 \\
\hline Variance & 0.56 & 0.847311828 \\
\hline Observations & 25 & 31 \\
\hline Hypothesized Mean Difference & 0 & \\
\hline df & 54 & \\
\hline t Stat & -2.03666784 & \\
\hline$P(T<=t)$ one-tail & 0.023299432 & \\
\hline t Critical one-tail & 1.673564906 & \\
\hline$P(T<=t)$ two-tail & 0.046598864 & \\
\hline t Critical two-tail & 2.004879288 & \\
\hline
\end{tabular}

3) Attribute: Extracurricular Involvement-Importance

Variable $1=$ Employer Ranking

Variable 2 = Student Ranking

Ho: $\bar{x}_{1}=\bar{x}_{2}$

Ha: $\bar{x}_{1} \neq \bar{x}_{2}$

\begin{tabular}{|c|c|c|}
\hline \multicolumn{3}{|c|}{$\begin{array}{l}\text { t-Test: Two-Sample Assuming Unequal Variances } \\
\text { Attribute: Extracurricular Involvement }\end{array}$} \\
\hline & Variable 1 & Variable 2 \\
\hline Mean & 3 & 3.741935484 \\
\hline Variance & 0.833333333 & 0.597849462 \\
\hline Observations & 25 & 31 \\
\hline \multicolumn{3}{|l|}{ Hypothesized Mean } \\
\hline Difference & 0 & \\
\hline$d f$ & 47 & \\
\hline t Stat & 3.234414483 & \\
\hline $\mathrm{P}(\mathrm{T}<=\mathrm{t})$ one-tail & 0.001116655 & \\
\hline t Critical one-tail & 1.677926722 & \\
\hline $\mathrm{P}(\mathrm{T}<=\mathrm{t})$ two-tail & 0.00223331 & \\
\hline t Critical two-tail & 2.011740514 & \\
\hline
\end{tabular}

4) Attribute: Internship Experience-Importance

Variable 1 = Employer Ranking

Variable 2 = Student Ranking

Ho: $\bar{x}_{1}=\bar{x}_{2}$

Ha: $\bar{x}_{1} \neq \bar{x}_{2}$

\begin{tabular}{|c|c|c|}
\hline \multicolumn{3}{|c|}{$\begin{array}{l}\text { t-Test: Two-Sample Assuming Unequal Variances } \\
\text { Attribute: Internship Experience }\end{array}$} \\
\hline & Variable 1 & Variable 2 \\
\hline Mean & 4.28 & 4.548387097 \\
\hline Variance & 0.46 & 0.389247312 \\
\hline Observations & 25 & 31 \\
\hline Hypothesized Mean Difference & 0 & \\
\hline $\mathrm{df}$ & 49 & \\
\hline t Stat & 1.525410227 & \\
\hline $\mathrm{P}(\mathrm{T}<=\mathrm{t})$ one-tail & 0.066792999 & \\
\hline t Critical one-tail & 1.676550893 & \\
\hline$P(T<=t)$ two-tail & 0.133585998 & \\
\hline t Critical two-tail & 2.009575237 & \\
\hline
\end{tabular}

